\title{
OPENNESS IN HIGHER EDUCATION
}

\author{
Tatiana Chiriac ${ }^{1}$
}

\begin{abstract}
The purpose of this study is to analyze the phenomenon of openness in higher education and its trends and technologies of expanding educational opportunities in the digital information society of Moldovan universities. The main concepts of openness in education are associated with the practice of online learning and constructivist approaches, technical optimization of delivering information, continuous professional development and globalization of higher education. Since skilled knowledge becomes the main value of the market, then higher education perspective as a tool of knowledge reproduction is transformed into the basic space of openness and accommodation to innovative use of educational resources. The key issues related to openness in order to impact higher education target the development of Open Educational Resources (OER), as well as implication of Massive Online Open Courses (MOOCs), relatively new online learning trend. There are institutional practices of the adoption and use of open education technologies in some international universities and organizations, which could be extended as well to create an open learning system in the Republic of Moldova, focusing on national practices of education. Openness of Moldovan HEIs is a strategic choice for the future in a rapidly changing educational market that should proliferate.
\end{abstract}

\section{Introduction}

In recent years open education and its technologies of expanding educational opportunities became significant in the European policy agenda. The main reasons of its impact are related to widening participation in higher education, increase of academic institutional visibility and team-based internationalization, enhance of learning outcomes and employability results. A review of literature on open education [3], [7] pointed out the necessity to become aware of open education in higher institutions and the importance of all features of openness in education by emphasis open best practices in teaching and learning and quality of them for regular students.

There are many European initiatives that support openness in online and flexible education (i.e. SCORE2020 $2, \mathrm{HOME}^{3}, \mathrm{ECO}^{4}$ etc.) in order to offer theoretical, practical and methodological approach, planned to help users to implement new pedagogical experience into learning process as well as to create open courses. Boudreau (2014) affirms that "openness in education can be exemplified through expressions of iterative socio-technological innovations that erode barriers and create multiple opportunities for practice-learning, teaching, and the development of content and learning environments" [1].

A lot of Internet technologies are available to enable openness, when Moldovan higher educational institutions are willing to involve multiple functionalities and approaches.

\footnotetext{
${ }^{1}$ Ion Creanga Pedagogical State University from Chisinau, Cathedra of Informatics and Information Technologies in Education, tcroitor_2000@yahoo.com

${ }^{2}$ Support Centres for Open education and MOOCS in different Regions of Europe 2020, http://score2020.eadtu.eu/

${ }^{3}$ Higher Education Online: MOOCs the European way, http://home.eadtu.eu/

${ }^{4}$ Elearning, Communication and Open-data: Massive Mobile, Ubiquitous and Open Learning, https://ecolearning.eu/
} 
This article presents a short analysis of the key issues related to open education models, which represent diverse kinds of openness due to multiple possibilities of interpretation, as well as how this trend are running in the Republic of Moldova.

\section{General principles}

Open education is the emergent paradigm of interaction between education and information technology and includes free tools, resources and practices used and shared in the digital environment. Open education underlines the power of the Internet tools and systems by offering free access, choice of start times and open availability of content and resources to every individual. In most cases, open education is a generic broad notion under which different meanings of openness could be fitted, such as Open Educational Resources (OER) and Massive Open Online Courses (MOOCs).

The concept of Open Educational Resources recommended by UNESCO Forum in 2002 is: "the open provision of educational resources, enabled by information and communication technologies, for consultation, use and adaptation by a community of users for non-commercial purposes" [4, p.24]. Up to now many other OER descriptions have been offered. Basic understanding of OER is broadly defined and includes different types of learning supports for course material, lists of references and lectures, experiments and demonstration materials, curricula and guides for teachers, educational articles, modules, simulations and so on. OER is a primordial term that comprises open textbooks and open courseware. Besides learning materials themselves, the Open Educational Resources may include tools and software required to develop, use and deliver education materials, including content organization within virtual learning and training communities.

The Open Educational Resources are generally characterized by the following specifications [5]:

- $\quad$ open content means free open access for educational institutions and individual users;

- $\quad$ licensed content, so it can be reused / modified in educational activities;

- $\quad$ educational applications are open source and can be modified / adapted.

Use of the OER leads to the following advantages for institutions and educational networks:

- $\quad$ provide lasting cooperation framework during creation and use of educational resources;

- make efficient public funds investments by sharing collective resources of institutions and professional communities;

- $\quad$ encourage development of digital competences, critical thinking and creativity;

- innovate curricula and teaching-learning methodologies, including resources of public libraries, museums and other cultural organizations;

- facilitate continue learning and social inclusion through open access to resources that otherwise would be unattainable for many user groups. 
Thinking about learner facilities, use of the OER has the following advantages:

- $\quad$ open educational resources cover a wide variety of topics;

- $\quad$ materials and references can be used / reused for teaching, learning, evaluation;

- ORE allow teachers to participate in validation and improving of resources through given feedback;

_ $\quad$ participation in learning communities via blogs, wikis, social networks;

- $\quad$ focus on promoting learning and education during the whole life;

- acquire essential skills necessary to knowledge society: critical thinking, personal development and creativity, solving practical problems, collaboration and communication.

Another technology of open education is the content of Massive Open Online Courses (MOOCs). MOOCs are open, free and online higher education courses. A MOOC course can always be accessed by anyone anywhere as long as they have an internet connection. Usually MOOCs are designed for large numbers of participants and offer a complete course experience online.

"MOOCs started in Canada and the US, and their rise to prominence was to a large extent driven by service providers such as Udacity, Coursera and Edx." [2] Each of these platforms could be joined by open students, who pay nothing to participate in the course activities, which might include reading educational materials, watching videos, making home works and writing exercises, discussing and commenting via social platforms. The enrolled students have access to recorded class lectures and course materials, as well as to a set of social networking tools that allows group interaction, resulting in a new learning collaborative and conversational chances for students to discuss the course content.

The MOOCs allow universities to open its curriculum to a larger audience, extending the institution's prestige into the community and removes barriers to learning.

Open strategies are essential for the continuous learning - online free education is introduced by both OER and by MOOCs. Open access in higher education from the world's top universities (Stanford, Princeton, Harvard, University of Edinburgh, University of Toronto and so on ${ }^{5}$ ) was already proven to be profitable for society. Open education should be next essential, integrated step to enhance the circulation and quality of knowledge in Moldova universities.

\section{Pedagogical principles}

The open frame for higher education foresees a pedagogical strategy to widen access to learners and thus to increase both the institution's reputation and visibility and the quality of the university courses. This strategy includes different dimensions to open up education, specifically methodological approach, content and educational material, technology, research, and collaboration.

\footnotetext{
${ }^{5}$ https://www.coursera.org/, https://www.edx.org/
} 
Each dimension has an intrinsic relationship with one another and allows for different degrees of openness [3].

Improvement of the educational outlook via open tools requires new skills and attitudes, if they are to concur successfully to an open pedagogy. Through open pedagogical approaches, every learner can have suitable and meaningful educational opportunities, which comprise the access to courses, guided support, assessment and certification in a modern and flexible way. Designing open education strategy brings opportunities to adopt and promote modernization, collaborative learning, learning through discovery and so on. Open strategy offers multiple means of teaching and learning, building and sharing knowledge and enables institutions to be eligible for international collaboration. Thus, university knowledge, practices and opportunities can be available to learners outside their geographical position.

Considering the role of openness in Higher Educational Institutions of Moldova, OER and MOOCs could be some excellent tools to produce and exchange teaching and learning materials, to gain world trustability and consideration, and thus to attract more international students. According to [10], HEIs "should aspire both to create OER and to use OER from elsewhere. (...) By making such resources an integral part of the teaching and learning process, limited face-to-face teaching time with students can be more effectively used to foster engagement and to nurture discussion, creativity, practical applications and research activities".

The case study of Open Education Research Hub shows that good qualitative courses available online appeal new students, enhance institutional reputation and impact professional development [11]. Institutions that use open education are collaborative and outside looking, are characterised by their international level quality and support the creation, development and transmission of social, cultural and economic values. The open technologies not only enlarge teaching and learning practices, but also create possibilities for new resources and teacher education materials to be fitted to the national context in terms of culture, habits, learning practices and needs, e.g. pedagogy, language, and cultural thesaurus. Also, the success and recognitions of open education technologies is conditioned by the quality of educational content and is valued by students and employers.

According to open education dimensions that establish openness of educational practices there are four aspects to be considered in designing and delivering OER: (1) designing an opening up education strategy for a university, (2) configuring the technological infrastructures and software which facilitate opening up education, (3) strengthening the quality of open education, (4) and promotion of leadership in open education. [3]

Thinking through these issues, it is significant to discover certain interpretations of openness which can revive educational opportunities, be fully accessible throughout their circumstances and ensure quality improvement of Moldovan university courses.

The goal of bringing openness in Moldovan HEIs is to establish pedagogical practices via ICTs for the purpose to intensify the effectiveness of learning design and growth students' involvement and collaboration. Open pedagogy makes pedagogical practices visible, transparent and available and also permits learners to plan their own learning way by offering them a large selection of learning resources. Collaboration connects individuals and institutions to exchange educational practices and resources with a view to improving education. By collaborating with each other and with the institution and community via networks, learners and institutions remove boundaries of education in order to produce knowledge, determine their learning route and achieve their aims. 
Moldovan universities, like Pedagogical State University and others, have a traditional and durable educational system that attract a narrow range of potential students from Moldova and very few from abroad. Inner students practice an education that is opportune and responsive to their personal growth, becoming fully engaged citizens within society, but all system rather is isolated than open. That's why open education can introduce a robust penetration for innovation education implementation in quotidian pedagogical processes and brings significant impact and international visibility of Moldovan HEIs. Or, integration of open dynamic components into a range of university activities could develop critical approaches to pedagogy.

Nevertheless, most universities of Moldova use e-learning online platforms, mainly Moodle, to train students and support learning process, whose materials are produced by university course teachers of their own initiative, voluntary. These university courses, opened just for discipline students, during one or two semester, consist of a suite of distance learning resources and tools. Each Moodle course focuses on subject modules related to university discipline, with a curriculum designed and developed by subject matter teachers. The modules are being constructed using blended e-learning methods, also providing interactive activities for self-paced learning. These e-learning initiatives are modern and flexible, but all these courses offered within Moodle platforms at the moment are opened just for a dozen of disciplines' learners, not free for everyone to use (e.g. moodle.upsc.md ${ }^{6}$ ).

In order to improve higher education systems through given potential of OER, UNESCO and the Commonwealth of Learning have developed Guidelines about all aspects of OER to support and make suggestions for integrating OER into higher education. [10], [12] In this way, considering UNESCO strategies and good worldwide experiences ${ }^{7}$, Moldovan open education initiatives, in present very modest, have started to develop with the regards to education institutions and academic staff. In author's opinion, improving the quality of teaching and learning through openness will develop a flexible and strong path that even led to future structural and quality reforms of Moldovan HEIs.

\section{Legislative Framework and Case Studies of Open Education in Moldova}

Developing human potential is one of the main responsibility of the process of modernization of the educational system in the Republic of Moldova. Considering to be a national priority, the Moldovan educational system acts in the base of legislative laws which are applied for the reform of the entire education system and follow to the best educational practices of the world. According to Activity Program of Moldovan Government 2016-2018 [6], upgrading the infrastructure of public institutions oriented towards innovation, relevance, efficiency, equitable access to education and implementation of mechanisms to ensure openness requires educational institutions to be prepared to develop, provide and use information services anytime, anywhere and via any device in a secure way.

The National Strategy for Information Society Development "Digital Moldova 2020"8 [8] underlines the necessity of increasing efficiency, expansion and diversification of national education through the opportunities offered by Information and Communication Technology. Another strategic document, the Education Development Strategy for 2014-2020 years "Education

\footnotetext{
${ }^{6}$ Learning Management System of Pedagogical State University

${ }^{7}$ Open Education Consortium - http://www.oeconsortium.org/, Commonwealth of Learning - http://www.col.org/, OpenStax - http://cnx.org/, OER Center - http://owli.org/oer/ etc.

${ }^{8}$ approved by Government Decision no. 857 on October 31,2013
} 
2020"9 [9] specifies concrete directions and priority actions referring to digital literacy by developing and applying digital educational content into didactic process, including use of existing open digital educational content (e.g., Discovery School, Khan Academy and others) and enhancing quality of higher education by integrating online courses (Massive Open Online Courses - MOOCs) into the university curriculum. Thus, open, accessible and quality education is declared by Government and Ministry of Education of Moldova as one of the most important priorities, which must be based on human capital development and growth of competitiveness of national economy.

However, the issue of openness is still on the agenda and is closely linked to the financial coverage and profound crisis in the field of educational system of Moldova.

With regard to good practices in the case of Europe, there are policies developed at the level of the European Union: Open Data, Open Access and Open Heritage policies. Some of the European states (UK, France, Denmark, Netherlands and Sweden) are among the leaders in the development of open policies. [13] There are many examples found by review of the specialized literature and website searches, which demonstrate the positive impact of open education in different European countries through the access to OER and MOOCs, that could be implemented in national educational system as good practices of openness in education, namely: France Université Numérique provides free classes in every discipline, Delft University of Technology actives in the area of open teaching, Madrid University provides MOOCs, Virtual University of Bavaria offers free online courses and others examples [3]. Open education projects can expand the approach to learning for everyone, but most of all for non-traditional groups of students, and thus widen participation in higher education.

In Republic of Moldova, open education production activities are at the incipient phase, but there are significant opportunities for the future. OER represent educational resources that can be used and reused freely by anyone without any technological, legal and cost restrictions. Making public programs by means of OER constitutes one of the basic principles of good governance: what is produced with public money should be publicly available free. In this context, during November 2015 - July 2016, the Educational Center Pro Didactica ${ }^{10}$, implemented the project Open Education in Moldova: Here and Now, with the financial support of the Institute for Open Society in cooperation with the Support Program of Education Foundations for Open Society. The purpose of the project was to promote the access of the interested public (academic staff, researchers, etc.) to create OER and to develop the concept of open educational resources, through awareness, support, coalition formation that may lead to ensure access to quality education for anyone. Another project Continuous Training of Teachers through Development of Massive Open Online Courses (MOOC), 2016-2019 implemented by Pedagogical State University of Chisinau is designed to establish open education strategy and to develop and implement a MOOC course into the Moldovan educational space.

These few projects emphasis the acute necessity for Moldova universities to find opportunities to integrate MOOCs and OER that could be particularly attractive and useful to vocational, part-time and international students. In this regard, more information concerning open education models should be discussed and disseminated in Romanian, because the majority literature and developers of OER and MOOCs are in English-speaking countries. Involving Moldova institutions in open

\footnotetext{
${ }^{9}$ approved by Government Decision no. 944 on November 14, 2014

${ }^{10} \mathrm{http}: / /$ red.prodidactica.md/
} 
education initiatives will broaden participation in higher education, improve training facilities and promote lifelong learning.

At the same time, the Moldovan Government and Ministry of Education need to stimulate the development of a National Open Learning Environment and to support actively all academic providers (teachers, schools, universities, and even the private sector) to become creators of digital resources and incorporate ICT in didactic activities. There is a need to examine the stimulus in order to get academic staff interested in contributing to open education.

Currently, in Republic of Moldova there is no a national framework and strategic policy for the development and use of open education.

\section{Conclusion}

The phenomenon of openness in higher education covers multiple opportunities to innovate teaching and learning context, including the ability to improve the affordability of education and enable better personalization of instruction. Openness impacts the main pylons of education curriculum, teaching, learning, research, context, and others. Open online model of learning can bring significant impact to HEIs of Moldova, because it gives the opportunities to implement pedagogical practices in accordance to digital society knowledge. The scope of using open resources in higher education of Moldova via OER and MOOCs is to enhance learning, to share qualitative knowledge and to strengthen social employability.

\section{References}

[1] BOUDREAU, A. Z., Openness in Education, Systems Thinking, and the Practitioner. In Proceedings of World Conference on Educational Multimedia, Hypermedia and Telecommunications Vol. 2014, No. 1 (Jun 23, 2014) pp. 1065-1071. Chesapeake, VA: AACE. Retrieved August 31, 2014 from http://www.editlib.org/p/147624. Accessed 23/11/2016.

[2] INAMORATO DOS SANTOS, A., et all. Opening up Education, A Support Framework for Higher Education Institutions, European Union, 2016, ISBN 978-92-79-58537-1, http://publications.jrc.ec.europa.eu/repository/bitstream/JRC101436/jrc101436.pdf. Accessed $05 / 12 / 2016$.

[3] SOUTO-OTERO, M., et al.: OpenCases: Case Studies on Openness in Education, JRC Science for Policy Report, European Union, 2016, ISBN 978-92-79-58536-4 http://publi cations.jrc.ec.europa.eu/repository/bitstream/JRC101533/jrc101533_opencases\%20case \%20st udies\%20on\%20openness\%20in\%20education.pdf.Accessed 10/11/2016.

[4] Programul de activitate al Guvernului Republicii Moldova 2016-2108, Chişinău 2016. http://www.gov.md/sites/default/files/document/attachments/guvernul_republicii_moldova__programul_de_activitate_al_guvernului_republicii_moldova_2016-20̄18.pdf. Accessed 02/10/2016.

[5] Strategia de dezvoltare a educaţiei pentru anii 2014-2020 „Educaţia-2020” (Aprobată prin hotărîrea guvernului nr.944 din 14 noiembrie 2014). http://lex.justice.md/index.php? action=view\&view=doc\&lang=1\&id=355494. Accessed 02/10/2016. 
[6] Strategia naţională de dezvoltare a societăţii informaţionale „Moldova Digitală 2020” (Aprobată prin Hotărîrea Guvernului nr. 857 din 31 octombrie 2013), http://www.mtic.gov. $\mathrm{md} /$ sites/default/files/transparency/public_consults/strateg_857.pdf._Accessed 02/10/2016.

[7] Forum on the Impact of Open Courseware for Higher Education in Developing Countries, Final report UNESCO Paris, 1-3 July 2002, http://unesdoc.unesco.org/images/0012/001285/ 128515e.pdf. Accessed 02/10/2016.

[8] JANSEN, D. and SCHUWER, R.: Institutional MOOC strategies in Europe. Status report based on a mapping survey conducted in October - December 2014. EADTU, February 2015, ISBN 978-90-79730-15-5. http://eadtu.eu/documents/Publications/OEenM/Institutional_ MOOC_strategies_in_Europe.pdf. Accessed 10/12/2016.

[9] PAVEL BURLOIU, V., CHIRVASE, T., MANOLEA, B. and VOICU, O., et alia: Ghid de bune practici RED, 2014, http://www.apti.ro/sites/default/files/Ghid-Resurse-educationaledeschise_0.pdf. Accessed 18/12/2016.

[10] Guidelines for Open Educational Resources (OER) in Higher Education, UNESCO and Commonwealth of Learning 2011, 2015, http://unesdoc.unesco.org /images/0021/002136/ 213605e.pdf.

[11] The Open Education Research Hub of Institute of Educational Technology, UK. Case Study. http://oerhub.net/what-we-do/case-studies/.

[12] BUTCHER, N.: A Basic Guide to Open Educational Resources (OER), UNESCO and Commonwealth of Learning 2011, 2015, http://unesdoc.unesco.org/images/0021/002158 /215804e.pdf.

[13] Global Open Policy Report 2016, Creative Commons Attribution 4.0 International License. https://creativecommons.org/wp-content/uploads/2016/12/StateofOpenPolicyFullReport_ FINAL-1-1-1-1.pdf. 